\title{
Muroto Project: Scientific Drilling of the Late Pliocene Forearc Basin Deposit on the West Coast of Muroto Peninsula, Shikoku, Japan
}

by Yasuo Kondo, Masao Iwai, and Kazuto Kodama

doi:10.2204/iodp.sd.3.08.2006

The Muroto Peninsula on the Pacific margin of southwest Japan (Fig.1) formed as a result of tectonic events associated with oblique subduction along the Nankai Trough (Sugiyama, 1992, 1994). Late Pliocene forearc basin deposits of the Tonohama Group are exposed on the west coast of the peninsula. Until recently, stratigraphical and paleontological data have been collected only from rather scattered and poorly exposed outcrops (e.g., Yokoyama, 1926; Katto, et al., 1953; Kurihara, 1968; Nishida, 1979; Okumura and Takei, 1993), and no detailed chronological and sequence-stratigraphic framework has been established. The paleoenvironmental changes recorded in the formation thus remain poorly understood.

To overcome these problems, the Muroto Scientific Drilling Project was initiated. It focuses primarily on the Ananai Formation, the uppermost unit of the Tonohama Group. During this project seventy meters of Tonohama sediment core were drilled (Fig.2) in Yasuda-cho, Kochi Prefecture, the type locality of this group. The core covers about two-thirds of the Ananai Formation and overlying terrace deposits. To obtain a general magnetostratigraphic view and to locate polarity boundaries, whole-core measurements were made using a pass-through cryogenic magnetometer located onboard the drilling vessel Chikyu. The core then was sampled more densely at portions containing the possible polarity transitions and excursions, and those samples were measured at an onshore laboratory of the Center for Advanced Marine Core Research at Kochi University, Japan. By now the core description is nearly

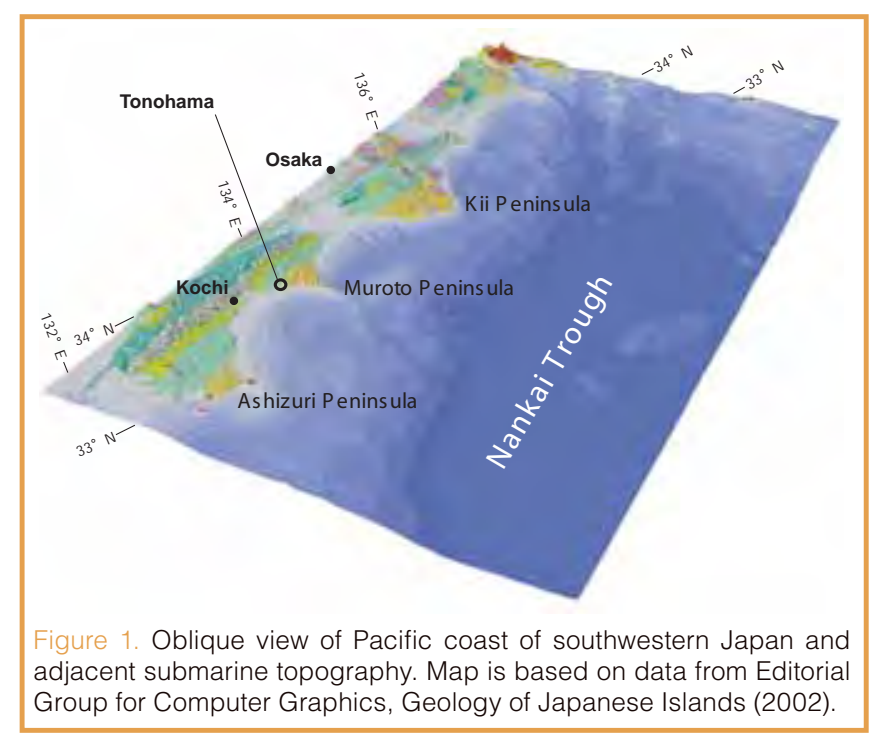

finished, and the density, porosity, and other physical properties were measured with a Multisensor Core Logger.

At least seventeen sedimentary cycles are recognized in the core, some of which can be correlated to those identified in surface exposures and confirmed to be transgressiveregressive cycles based on the stratigraphic distribution of mollusks (Kondo, et al., 1997). Also, vertical changes in cycle thickness can be recognized; the cycles tend to become thicker upwards, indicating a general increase of the sedimentation rate in the younger cycles.

An examination of outcrops has shown that transgressiveregressive environmental changes probably originated from glacial to interglacial climatic oscillations (Kondo et al., 1997). To analyze the cycles in detail, a complete stratigraphy needs to be established for the recovered core. This will allow us to reconstruct the habitat distribution and ecology of the fauna and address the relation between composition of the fossil associations and sedimentation rate.

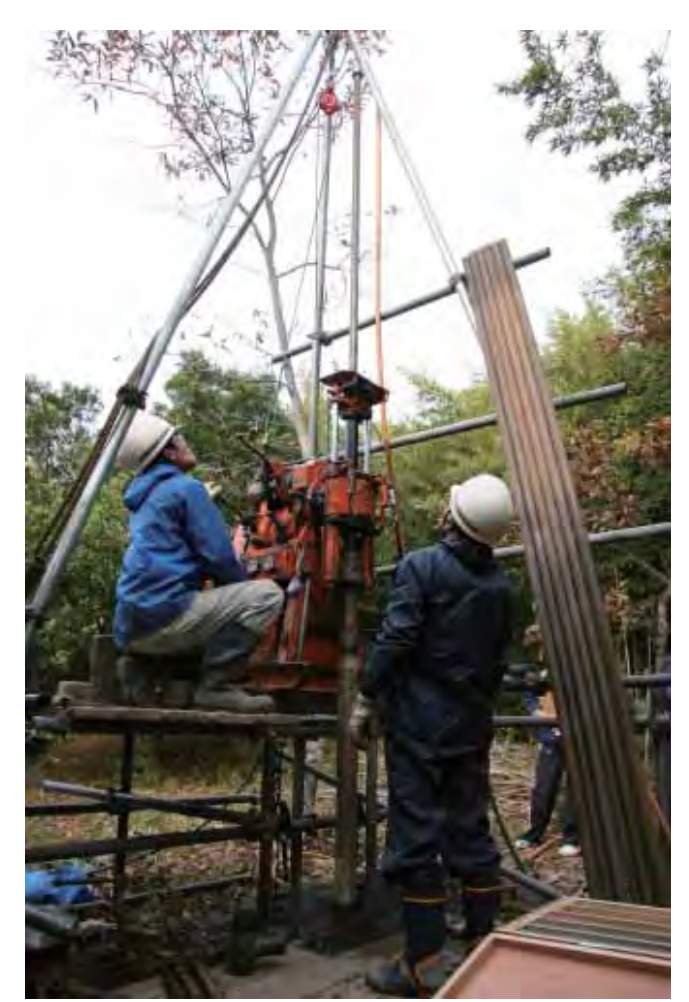

Figure 2. Core operations on a terrace in Tonohama, near type locality of Ananai Formation. 
Analysis of the nannofossil assemblages from the contemporaneous strata on the Boso Peninsula (Central Japan) by Kameo et al. (2003) revealed a cooling event at approximately $2.7 \mathrm{Ma}$ and an increased inflow of nutrient-rich surface water that originated from nearshore waters along the East Asian continental margin. This was interpreted to reflect the intensified weathering of the East Asian continent, as related to tectonic and climate processes around the HimalayanTibetan Complex and consistent with studies in Lake Baikal (e.g. Müller et al., 2001). Given its location in the southern extension of the Boso Peninsula, the Ananai Formation may contain key strata which help to understand the origin and development of the nutrient-rich surface waters during this period.

Records of paleomagnetic polarity reversals of the core show two normal and three reversed polarity zones with four polarity boundaries representing magnetic transitional zones of 40-60 cm thickness (Fig. 3). Each zone correlates with the Pliocene magnetic polarity time scale, although precise polarity assignment needs independent constraints through micropaleontological and isotope investigations currently underway. The very high resolution magnetostratigraphic record will enable precise age estimation of the Ananai Formation and provide new information on the behavior of the geomagnetic field during transitions of the Pliocene polarity subchrons.

\section{References}

Editorial Committee for the Geology of the Japanese Islands, 2002. Computer Graphics, Geology of the Japanese Islands, CDROM version, Maruzen Co. Ltd., Tokyo.

Kameo, K., Saito, K., Kotake, N., and Okada, M., 2003. Late Pliocene sea surface environments in the Pacific side of Central Japan based on calcareous nannofossils from the lower part of the Chikura Group, southernmost part of the Boso Peninsula. Journal of the Geological Society of Japan, 109:478-488. (in Japanese with English abstract)

Katto, J., Nakamura, J., and Takayanagi, Y., 1953. Stratigraphical and paleontological studies of the Tonohama Group, Kochi Prefecture, Japan. Sci. Rep., Kochi Univ., 2:1-15, tables 1-7. (in Japanese with English abstract)

Kondo, Y., Kikuchi, N. and Hirose, K., 1997. Late Pliocene shelf to nearshore sedimentary cycles and paleoecology of macrobenthic invertebrates. Abstracts with programs, 146th meeting, Palaeontological Society of Japan, 20. (in Japanese)

Kurihara, K., 1968. Notes on the benthonic foraminifera of the Tonohama Group, Shikoku, Japan. Trans. Proc. Palaeont. Soc. Japan, N. S., 70:267-283.

Müller, J., Oberhänsli, H., Melles, M., Schwab, M., Rachold, V., and Hubberten, H.-W., 2001. Late Pliocene sedimentation in Lake Baikal: implications for climatic and tectonic change in SE Siberia. Palaeogeogr. Palaeoclimatol. Palaeoecol., 174:305-326, doi:10.1016/S0031-0182(01)00320-0.

Nishida, S., 1979. Restudies of calcareous nannoplankton biostratigraphy of the Tonohama Group, Shikoku, Japan. Nara Univ. Educ., Bull., 28:97-110.

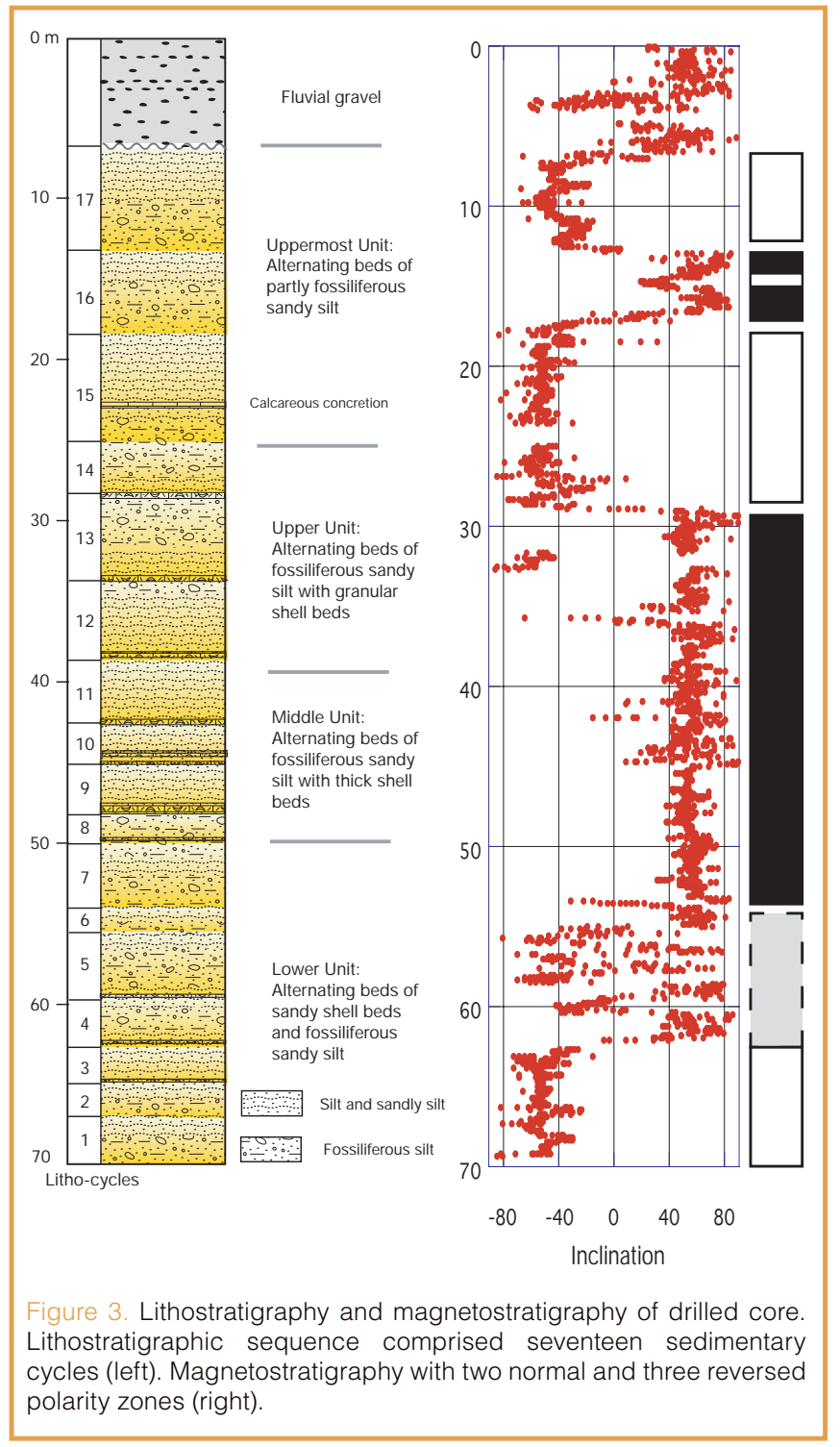

Okumura, K., and Takei, T., 1993. Molluscan assemblages from the Late Pliocene Ananai Formation, Kochi Prefecture, southwest Japan. Bull. Mizunami Fossil Mus., 20:133-183, 14 plates.

Sugiyama, Y., 1992. Neotectonics of the forearc zone and the Setouchi Province in Southwest Japan. Mem. Geol. Soc. Japan, 40:219-233. (in Japanese with English abstract)

Sugiyama, Y., 1994. Neotectonics of Southwest Japan due to the rightoblique subduction of the Philippine Sea plate. Geofisica Internacional, 33:53-76.

Yokoyama, M., 1926. Tertiary shells from Tosa. J. Fac. Sci. Imp. Univ. Tokyo (Ser. II), 1:365-368.

\section{Authors}

Yasuo Kondo, Department of Natural Environmental Science, Kochi University, Kochi 780-8520, Japan, e-mail: ykondo@cc.kochi-u.ac.jp

Masao Iwai, Department of Natural Environmental Science, Kochi University, Kochi 780-8520, Japan.

Kazuto Kodama, Center for Advanced Marine Core Research, Kochi University, B200 Monobe, Nankoku, Kochi 783-8502, Japan. 